\title{
OASES-ITSEARVIOINTILOMAKKEIDEN SUOMENNOSTEN VALIDITEETTI JA RELIABILITEETTI
}

\section{Eira Jansson-Verkasalo*, Psykologian ja logopedian laitos, Turun yliopisto}

Auli Laiho*, Voimavarakeskus Tempo Oy

J. S. Yaruss, Communicative Sciences and Disorders, Michigan State University, East Lansing, MI

* Kirjoittajat jakavat ykköskirjoittajuuden

Overall Assessment of the Speaker's Experience of Stuttering (OASES ${ }^{\mathrm{TM}}$; Yaruss \& Quesal, 2016) -itsearviointimenetelmä mittaa änkyttävän henkilön kokemuksia änkytyksestä hänen omasta näkökulmastaan. Tutkimuksemme tavoitteena oli arvioida alakouluikäisten OASES-S-, nuorten OASES-T. ja aikuisten OASES-A-itsearviointimenetelmän suomennosten pätevyyttä (validiteettia) ja luotettavuutta (reliabiliteettia). Tutkimuksessa 60 änkyttävää lasta täytti OASES-S:n (60 kysymystä), 31 änkyttävää nuorta OASES-T:n (80 kysymystä) ja 31 änkyttävää aikuista OASES-A:n (100 kysymystä). Mittareiden ulkoinen validiteetti, rakennevaliditeetti ja sisällön validiteetti todettiin hyväksi, joten itsearviointilomakkeet arvioivat pätevästi vastaajien kokemusta änkytyksen vaikutuksesta elämänlaatuun. Eri ikäisille suunnattujen itsearviointilomakkeiden alfakertoimet olivat korkeat (a 0,82-0,95) osoittaen hyvää sisäistä konsistenssia, ja mittaustulosten pysyvyys oli hyvä ( $r=0,65$ 0,97), lukuun ottamatta OASES-A:n osaa yleiset tiedot. Tutkimus osoitti, että suomennetut OASES-itsearviointilomakkeet erottelevat änkyttävien ihmisten kokemuksia änkytyksen vaikutuksesta heidän elämänlaatuunsa pätevyyden lisäksi luotettavasti. Vaikutuksen luokitukset olisi kuitenkin hyvä muuttaa suomalaisen kliinisen käytänteen mukaisiksi. Lisätutkimuksia tarvitaan kulttuurierojen vaikutuksesta änkytyksen kokemukseen ja sen itsearviointiin arviointimenetelmien sensitiivisyyden parantamiseksi.

Avainsanat: arviointimenetelmä, elämänlaatu, OASES, änkytys

Kirjoittajien yhteystiedot:

Eira Jansson-Verkasalo

eira.jansson-verkasalo@utu.fi
Auli Laiho

auli.e.laiho@gmail.com 


\section{JOHDANTO}

Änkytyksessä puheen äänteet, tavut tai sanat toistuvat tiheään tai pitkittyvät, tai usein toistuvat sujumattomuudet ja tauot särkevät puheen rytmin. Puheen toistoihin, pitkittymisiin tai taukoihin saattaa liittyä samanaikaisia kasvojen tai muiden ruumiinosien liikkeitä (WHO, 2016, Kansainvälinen tautiluokitus ICD-10). Yksinkertaisimmillaan änkytys siis tarkoittaa vaikeuksia tuottaa puhetta sujuvasti (ks. esim. Bloodstein \& Ratner, 2008, s. 1). Kokemus änkytyksestä on kuitenkin puhujalle usein paljon enemmän kuin puheen sujumattomuus (ks. esim. Bloodstein \& Ratner, 2008, s. 21-26; De Nil \& Brutten, 1991; Manning \& DiLollo, 2018, s. 207-209, 212-222; Murphy ym., 2007a, 2007b; Van Riper, 1982, s. 157-190; Vanryckeghem \& Brutten, 1996; Vanryckeghem ym., 2001; Yaruss, 1998; Yaruss \& Quesal, 2004), ja ICD-10:n määritelmä jääkin pinnalliseksi ja suppeaksi. Sitä täydentämään on rakentunut Maailman Terveysjärjestön malli The International Classification of Functioning, Disability, and Health (ICF), jonka avulla on mahdollista kuvata minkä tahansa sairauden tai vamman vaikutusta yksilön toimintakykyyn (WHO, 2001; Terveyden ja hyvinvoinnin laitos, 2013). ICF:ssä on kaksi osa-aluetta, kehon ja ruumiin rakenteet ja toiminnot sekä aktiivisuus ja osallistuminen. Lisäksi siinä määritellään kontekstuaalisiksi tekijöiksi yksilö- ja ympäristötekijät. Nämä kontekstuaaliset tekijät vaikuttavat siihen, miten kehon ja ruumiin rakenteiden ja toimintojen pulmat heijastuvat aktiivisuuteen ja osallistumiseen.

ICF-malli soveltuu hyvin kuvaamaan änkytyksen vaikutuksia elämänlaatuun (ks. esim. Yaruss, 2007; Yaruss \& Quesal, 2004). Änkytykseen liittyviä yksilöllisiä tekijöitä ovat esimerkiksi kokemukset aiemmista puhetilanteista, ajatukset änkytyksestä, tunnereaktiot, änkytyksen aiheuttama haitta sekä yksilölle kehittyneet selviytymiskeinot.
Puhuja voi kokea mm. häpeää, suuttumusta ja turhautumista tai hän voi tuntea olonsa eristäytyneeksi ja yksinäiseksi änkytyksen rajoittaessa vuorovaikutustilanteissa toimimista. Änkytyksen on havaittu alentavan puhujan itseluottamusta ja johtavan heikon itsetunnon kehittymiseen, herättävän puhumiseen ja kommunikointiin liittyviä riittämättömyyden tunteita sekä tuntemuksen siitä, että änkytyksestä ei voi selviytyä (Yaruss \& Quesal, 2004).

Ympäristötekijöillä on merkittävä vaikutus siihen, miten yksilö kokee änkytyksen. Puhujan ja kuulijoiden kielteiset reaktiot voivat heikentää puhujan mahdollisuuksia tehdä haluamiaan asioita ja johtaa rajoitteisiin osallistumisessa ja aktiivisuudessa (Yaruss \& Quesal, 2004, 2016). Puhuja voi oppia välttelemään tiettyjä äänteitä tai sanoja tai jopa kokonaisia puhetilanteita. On tavallista, että puhelimessa puhuminen, itsensä esitteleminen, esitelmien tai puheiden pitäminen, kokouksiin osallistuminen sekä puhuminen ajan paineessa voivat olla vaikeita (Erickson \& Block, 2013). Välttelykäyttäytyminen onkin johdonmukainen seuraus änkytyksen aiheuttamasta häpeästä ja riittämättömyyden kokemuksesta. Välttelyn seuraukset voivat ulottua yksittäisiä sanavalintoja tai puhetilanteita laajemmalle, sillä joskus puhuja ei esimerkiksi uskalla mennä työhaastatteluun, tutustua mahdollisiin seurustelukumppaneihin tai uusiin ystäviin.

Kokemus erilaisuudesta ja vaikeudesta toimia vuorovaikutustilanteissa herättää usein ahdistusta. Tutkimuksissa sosiaalisen ahdistuneisuuden yhteys änkytykseen tulee toistuvasti esille, mutta sen yleisyys vaihtelee. Menziesin ym. (2008) aineistossa sosiaalista ahdistuneisuutta oli jopa 2/3:1la puheterapiaan änkytyksen vuoksi hakeutuneista aikuisista, kun taas Iverachin ym. (2010) aineistossa näin oli neljäsosalla tutkittavista. Usein korostuu myös pelko arvostelluksi tulemisesta (ks. esim. Iverach \& Rapee, 2014). Lisäksi erilai- 
set mielialahäiriöt, kuten vakava masennus, sekä persoonallisuushäiriöt ovat änkyttävien aikuisten keskuudessa 2-3 kertaa yleisempiä kuin sujuvilla aikuisilla (Iverach ym., 2009; 2010). Änkytyksen kielteiset vaikutukset voivat tulla näkyviin jopa ennen kouluikää (Ezrati-Vinacour ym., 2001; Langevin ym., 2009).

Änkytyksen vaikutus elämänlaatuun ja ihmisen tekemiin valintoihin on laaja-alaista. Änkytys vaikuttaa sosiaalisiin suhteisiin ja voi liittyä kokemukseen yksinäisyydestä (Daniels ym., 2012; Klombas \& Ross, 2004). Änkyttävät nuoret kokevat tulevansa kiusatuiksi ikätovereitaan useammin (Erickson \& Block, 2013). Änkytyksen on osoitettu olevan yhteydessä opinnoissa menestymiseen, ja nuoret keskeyttävät lukion herkemmin, jos kokevat änkytyksen vaikeasti häiritsevänä (O'Brian ym., 2011). On havaittu myös, että änkyttävät henkilöt hakeutuvat herkemmin matalapalkkaisiin töihin tai kokevat vaikeuksia työllistymisessä (Gerlach ym., 2018; McAllister ym., 2012). Kaikki nämä tekijät vaikuttavat puhujan osallistumiseen, toimintakykyyn ja elämänlaatuun (Yaruss, 1998, 2007; Yaruss \& Quesal, 2004, 2006).

Änkytyksen puheterapeuttisessa arvioinnissa on kansainvälisesti käytössä monia menetelmiä. Osa mittareista keskittyy vain puheen tuoton ja puheen sujuvuuden arviointiin. Änkytyksen määrää voidaan arvioida esimerkiksi laskemalla änkytettyjen tavujen prosentti tuotetuista 300 sanasta, jotka on koottu eri puhetilanteista (Conture, 2001). Yleisesti käytössä oleva menetelmä on Stuttering Severity Instrument, SSI-4 (Riley, 2009).SSI-4 arvioi änkytyksen vaikeusastetta änkytyksen määrän, änkytysten keston, pakenemisreaktioiden ja puheen luonnollisuuden kautta. Nämä puheen tuottoon painottuvat mittarit eivät kuitenkaan kerro siitä, millaista subjektiivista haittaa änkytys aiheuttaa. Etenkin aikuisten änkytyksen arvioinnissa itsear- vioinnilla on keskeinen merkitys yksilöllisen haittakokemuksen kartoittamisessa (O 'Brian ym., 2020).

Itsearviointiin on käytettävissä useita lomakkeita. Eri ikäryhmille kohdennetut Communication Attitude Test (CAT) -lomakkeet (BigCAT aikuisille, CAT kouluikäisille, KiddyCAT pienille lapsille) kartoittavat änkytykseen liittyviä kommunikointiasenteita totta/ väärin asteikolla (Brutten \& Dunham, 1989; Jansson-Verkasalo ym., 2021; Vanryckeghem \& Brutten, 2007, 2016). Myös aikuisille suunnattuun Ericksonin asteikkoon (39 kysymystä, tai sen muunnelma 24 kysymystä) vastataan totta/väärin, ja asteikon väittämät liittyvät käsityksiin itsestä puhujana (ks. esim. Andrews \& Cutler, 1974). Unhelpful Thoughts and Beliefs About Stuttering (UTBAS) puolestaan selvittää haitallisia ajatuksia ja uskomuksia, joita aikuinen tai nuori liittää änkytykseensä (ks. esim. St Clare ym., 2009). UTBAS sisältää 66 änkytykseen tyypillisesti liittyvää ajatusta, joista jokaista vastaaja arvio asteikolla 1-5 ajatuksen yleisyyden, uskottavuuden ja ahdistavuuden suhteen. The Wright and Ayre Stuttering Self-Rating Profile (WASSP) perustuu ICF-luokitukseen (Wright \& Ayre, 2000). Lomakkeessa on 24 kysymystä, joihin vastataan asteikolla 1-7. Kysymyksillä kartoitetaan seuraavia osa-alueita: puheen sujuvuus, ajatukset änkytyksestä, änkytykseen liittyvät tunteet, änkytyksen aiheuttama välttely ja änkytyksen aiheuttama haitta.

Tutkimuksen keskiössä ollut Overall Assessment of the Speaker's Experience of Stuttering (OASES ${ }^{\text {TM}}$; Yaruss \& Quesal, 2016) -itsearviointimenetelmä tutkii kokemuksia änkytyksestä änkyttävän henkilön omasta näkökulmasta. OASES on kehitetty ICF-mallin pohjalta ja se huomioi puheen tuoton ohella vastaajan kokemuksia änkytyksen vaikutuksista elämän eri osa-alueilla (Yaruss, 1998, 2007; Yaruss \& Quesal, 2004). OASES-arviointimenetelmän avulla voidaan kartoittaa 
änkytyksen vaikutuksia ihmisen elämään sekä seurata kuntoutuksen vaikuttavuutta. Muihin itsearviointimenetelmiin verrattuna OASES-itsearviointilomakkeiden vahvuus on kysymysten monipuolisuus ja ulottuminen oireisiin, toimintatapoihin, tunnereaktioihin, ympäristötekijöihin, osallistumiseen ja sen rajoittumiseen, sosiaalisiin suhteisiin ja elämänlaatuun. Vaikka myös WASSP perustuu ICF-malliin, päästään aikuisten OASESitsearviointilomakkeen sadalla kysymyksellä tarkastelemaan änkytystä syvällisemmin kuin WASSP:n 24:llä kysymyksellä. Lisäksi OASES sisältää erilaiset itsearviointilomakkeet alakouluikäisille lapsille (7-12 vuotta), nuorille (13-17 vuotta) ja aikuisille (18 vuotta tai vanhempi). Tämä mahdollistaa änkytykseen liittyvien kokemusten arvioinnin iän karttuessa. OASES tarjoaa puheterapeuteille välineen, jolla voi mitata änkytyksen vaikutuksia ihmisen elämään. Tämä poikkeaa monista muista änkytyksen arvioinnin menetelmistä, joilla on taipumus painottua puhehäiriön yksittäisiin osatekijöihin, kuten änkytyksen vaikeusasteeseen (ks. Yaruss \& Quesal, 2006).

OASES-lomakkeeseen vastataan asteikolla $1-5$, joka vastaa myös koko arviointilomakkeen änkytyksen vaikutuksen luokittelun asteikkoa. Alkuperäinen amerikkalainen, englanninkielinen OASES luokittelee änkytyksen vaikutukset elämänlaatuun lieväksi, lieväksi/keskivaikeaksi, keskivaikeaksi, keskivaikeaksi/vaikeaksi ja vaikeaksi. Amerikkalaisten vastaajien kokemusten jakautuminen eri luokkiin on esitetty ikäryhmittäin taulukossa 1 . Tulosten mukaan änkytyksen koetaan vaikuttavan elämänlaatuun kielteisemmin aikuisena kuin nuorena ja kouluikäisenä (Yaruss \& Quesal, 2016).

TAULUKKO 1. Änkytyksen vaikutus elämänlaatuun ikäryhmittäin amerikkalaisen normiaineiston mukaan (Yaruss \& Quesal, 2016).

\begin{tabular}{lccccc}
\hline \multicolumn{5}{c}{ Änkytyksen vaikutusta kuvaava luokittelu } \\
\hline Ikäryhmä & Lievä & $\begin{array}{c}\text { Lievä/ } \\
\text { keskivaikea }\end{array}$ & Keskivaikea & $\begin{array}{c}\text { Keskivaikea/ } \\
\text { vaikea }\end{array}$ & Vaikea \\
\hline & Pistemäärä & Pistemäärä & Pistemäärä & Pistemäärä & Pistemäärä \\
& $1,00-1,49$ & $1,50-2,24$ & $2,25-2,99$ & $3,00-3,74$ & $3,75-5,00$ \\
$\begin{array}{l}\text { Alakoulu- } \\
\text { ikäiset } \\
\text { (n= 75) }\end{array}$ & $7 \%$ & $40 \%$ & $48 \%$ & $4 \%$ & $1 \%$ \\
$\begin{array}{l}\text { Nuoret } \\
\text { (n= 45) }\end{array}$ & $11 \%$ & $33 \%$ & $38 \%$ & $16 \%$ & $2 \%$ \\
$\begin{array}{l}\text { Aikuiset } \\
\text { (n= 173) }\end{array}$ & $5 \%$ & $30 \%$ & $34 \%$ & $24 \%$ & $7 \%$ \\
\hline
\end{tabular}


OASES-itsearviointilomakkeet ovat laajasti käytössä ympäri maailmaa ja saatavilla ainakin kahdeksalla kielellä. Erikielisten itsearviointilomakkeiden pätevyys (validiteetti) ja luotettavuus (reliabiliteetti) on todettu hyväksi (ks. esim. Blumgart ym., 2012; Lindström ym., 2020; Sakai ym., 2017). Lindström ym. (2020) vertasivat ruotsalaisten henkilöiden itsearviointilomakkeilla saatuja pistemääriä muissa maissa raportoituihin itsearviointien pistemääriin, ja pohtivat eroja kulttuurisen maailmankartan pohjalta. Kulttuurikartassa Suomi ja Ruotsi sijoittuvat lähelle toisiaan. Ruotsalaisessa aineistossa itsearviointilomakkeilla saadut pistemäärät olivat alhaisempia kuin amerikkalaisessa, australialaisessa ja japanilaisessa aineistossa. Ero oli tilastollisesti merkitsevä aikuisten osalta ja sen pohdittiin heijastelevan sekä ruotsalalaisten yleistä myönteistä suhtautumista änkytystä kohtaan (ks. esim. St. Louis ym., 2016) että ruotsalaiselle puheterapialle tyypillistä myönteisen asennoitumisen ja änkytyksen hyväksymisen työstämistä.

\section{TUTKIMUKSEN TAVOITE}

Arviointimenetelmien kääntäminen kielestä toiseen on yleistä, sillä niiden kehittäminen alusta alkaen on pitkä ja työläs prosessi. Arviointimenetelmien kääntämisessä keskeisessä asemassa on kielellisen muodon lisäksi kulttuuristen merkityssisältöjen kääntäminen, jotta uusi mittari kykenisi mittaamaan samaa ilmiötä kuin alkuperäinen (WHO, 2017). Käännösten pätevyyden (validiteetti) ja luotettavuuden (reliabiliteetti) varmistamiseksi käännettyjä arviointilomakkeita tulee koekäyttää kohdepopulaatiolla. Toistaiseksi ei ole suomenkielisiä itsearviointilomakkeita, joilla voidaan arvioida änkytyksen vaikutusta laajasti elämänlaatuun eri ikäisenä ja joiden psykometrisia ominaisuuksia olisi tieteellisesti arvioitu.
Tämän tutkimuksen tavoitteena oli arvioida suomennettujen ja Suomen kulttuuriin mukautettujen alakouluikäisille suunnatun OASES-S- ( $\mathrm{S}=$ school-aged $)$, nuorille suunnatun OASES-T- $(T=$ teen-aged $)$ ja aikuisille suunnatun OASES-A- (A = adults) itsearviointilomakkeiden psykometrisia ominaisuuksia; validiteettia (ulkoinen validiteetti, rakennevaliditeetti ja sisällön validiteetti) ja reliabiliteettia (sisäinen konsistenssi, toistomittaus). Saman arviointimenetelmän käyttäminen eri ikäisillä antaa mahdollisuuden arvioida änkytyksen vaikutuksia ihmisen elämään eri ikäisenä sekä seurata puheterapian vaikuttavuutta. Tutkimuksen kliinisenä sovelluksena oli tuoda suomalaisten puheterapeuttien käyttöön monipuolinen itsearviointilomake änkytyksen vaikutusten arvioimiseen.

\section{AINEISTO JA MENETELMÄT}

\subsection{Tutkittavat}

Suomennettujen OASES-S-, OASES-T- ja OASES-A-itsearviointilomakkeiden vastaukset koottiin osana laajaa puheen sujuvuuden ja sen häiriöiden tutkimusprojektia. Tutkittavat ohjautuivat tutkimukseen puheterapeuttien välityksellä. Vastauksia saatiin yhteensä 122:lta henkilöltä, jotka änkyttävät. Suomenkielisen alakouluikäisten itsearviointilomakkeen (OASES-S) täytti 60 alakouluikäistä lasta, nuorten lomakkeen (OASES-T) täytti 31 nuorta ja aikuisten lomakkeen (OASESA) täytti 31 aikuista (taulukko 2). Prosentuaalisesti suurempi osa tutkittavista oli poikia/ miehï (taulukko 2). Ikäjakaumassa ei havaittu merkitsevää eroa sukupuolten välillä missään tutkittavien ryhmässä [alakouluikäiset $\left(\chi^{2}(1)=31,88, p=0,523\right.$; nuoret $\chi^{2}(1)=$ $23,72, p=0,419$; aikuiset $\chi^{2}(1)=23,53, p$ $=0,317$. 
TAULUKKO 2. Vastanneiden deskriptiiviset tunnusluvut.

\begin{tabular}{llll}
\hline & OASES-S & OASES-T & OASES-A \\
$\mathbf{n}=\mathbf{6 0}$ & $\mathbf{n}=\mathbf{3 1}$ & $\mathbf{n}=\mathbf{3 1}$ \\
\hline \multirow{2}{*}{ Sukupuoli } & 16 tyttöä $(26,7 \%)$ & 11 tyttöä $(35,5 \%)$ & 6 naista $(19,4 \%)$ \\
& 44 poikaa $(73,3 \%)$ & 20 poikaa $(64,5 \%)$ & 25 miestä $(80,6 \%)$ \\
\hline \multirow{2}{*}{ Ikä vuosina } & ka $10,5 \mathrm{v}$ & ka $14,9 \mathrm{v}$ & ka $35,1 \mathrm{v}$ \\
& kh 1,8 & kh 1,26 & kh 16,3 \\
& alin $7,2 \mathrm{v}$ & alin $13,0 \mathrm{v}$ & alin $18,0 \mathrm{v}$ \\
& ylin $13 \mathrm{v}$ & ylin $17,9 \mathrm{v}$ & ylin $67,0 \mathrm{v}$ \\
\hline
\end{tabular}

$\mathrm{ka}=$ keskiarvo, $\mathrm{kh}=$ keskihajonta

Änkytyksen vaikeusastearvioinnin suorittivat puheterapeutit, jotka olivat suorittaneet eurooppalaisen puheen sujuvuuden häiriöiden kliinisen erikoistumiskoulutuksen ja/tai heillä oli kokemusta änkytyksen arvioinnista ja kuntoutuksesta. Puheterapeutit arvioivat änkytysasteen viisiportaisesti OASES- lomakkeiden tapaan asteikolla 1-5. Tässä tutkimuksessa vaikeusarviot olivat 1 erittäin lievä, 2 lievä, 3 keskivaikea, 4 vaikea, 5 erittäin vaikea (taulukko 3). Vaikeusasteen arvio oli ilmoitettu 68,3\%:lta kouluikäisistä, 77,5\%:Ita nuorista ja 71 \%:Ita aikuisista.

TAULUKKO 3. Puheterapeutin arvioiman änkytyksen vaikeusasteen prosentuaalinen osuus eri ikäryhmissä.

\begin{tabular}{lccccc}
\hline & \multicolumn{5}{c}{ Änkytyksen vaikeusaste } \\
\hline $\begin{array}{l}\text { Ryhmä } \\
\text { (ilmoitetut vaikeusasteet) }\end{array}$ & $\mathbf{1}$ & $\mathbf{2}$ & $\mathbf{3}$ & $\mathbf{4}$ & $\mathbf{5}$ \\
\hline $\begin{array}{l}\text { Alakouluikäiset } \\
\mathbf{n}=\mathbf{4 1}\end{array}$ & $19,5 \%$ & $22 \%$ & $29,3 \%$ & $14,6 \%$ & $14,6 \%$ \\
$\begin{array}{l}\text { Nuoret } \\
\mathbf{n}=\mathbf{2 4}\end{array}$ & $8,3 \%$ & $33,3 \%$ & $12,5 \%$ & $29,2 \%$ & $16,7 \%$ \\
$\begin{array}{l}\text { Aikuiset } \\
\mathbf{n}=\mathbf{2 2}\end{array}$ & $4,5 \%$ & $31,8 \%$ & $36,4 \%$ & $9,1 \%$ & $18,2 \%$ \\
\hline
\end{tabular}

1 = erittäin lievä, 2 = lievä, $3=$ keskivaikea, 4 = vaikea. 5 = erittäin vaikea

Kaikkien tutkittavien äidinkieli oli suomi. Kielellinen suoriutuminen ja terveydentila varmistettiin alakouluikäisten lasten vanhempien täyttämän esitietolomakkeen avulla, ja nuoret ja aikuiset tutkittavat täyttivät itse omaa terveydentilaansa koskevan esitietolomakkeen. Esitietolomakkeessa tiedusteltiin muun muassa, onko vastaajalla muita puheen tai kielenkehityksen häiriöitä kuin änkytys, vastaajan tai hänen lähiomaistensa mahdollisia neurologisia sairauksia ja änkytyksen alkamisajankohtaa. Änkytykseen saattaa liittyä erilaisia kielellisiä häiriöitä (Choi ym., 2018; Singer ym., 2020). Kielellinen häiriö ei kuitenkaan ollut poissulkukriteeri, mikäli se ei estänyt itsearviointilomakkeiden kysymysten 
ymmärtämistä ja/tai kysymyksiin vastaamista. Yhtään vastaajaa ei poistettu tutkittavien joukosta ymmärtämisvaikeuksien vuoksi. Myöskään yhtään vastaajaa ei ollut tarvetta poistaa sen vuoksi, että hänellä olisi ollut taipumus vastata kaikkiin kysymyksiin samalla tavalla.

\subsection{Itsearviointilomakkeet}

OASES-itsearviointilomakkeiden käännösprosessi suoritettiin WHO:n (2017) laatiman käännösohjeistuksen mukaisesti alkuperäisen lomakkeen tekijän J. S. Yarussin suostumuksella ja yhteistyössä hänen kanssaan. Alkuperäiset lomakkeet suomensi kolme englannin kielen kääntämiseen ja änkytykseen perehtynyttä logopedian opiskelijaa (Laitinen, 2016; Mäntylä, 2017; Vahanne, 2017). Alkuperäisen käännöksen tarkasti ja mahdollisista muutoksista vastasi tutkimusprojektin johtaja yhdessä asiantuntijaraadin kanssa (RaukolaLindblom, Rautakoski). Takaisinkäännöksen suomesta englanniksi suoritti riippumaton, virallinen kielenkääntäjä. Takaisinkäännökset tarkasti OASES-kehittäjä, professori Yaruss. Lisäksi tutkimusprojektin johtaja ja testin kehittäjä keskustelivat ja sopivat Suomen kulttuuriin ja kliiniseen käytäntöön sopimattomien kysymysten muutoksista (esimerkiksi nuorten lomakkeen kysymys \#55 "order food in a restaurant or at a drive-thru" käännettiin suomeksi "ravintolassa tai grillikioskilla" ja kysymyksessä \#48 sana "coach" käännettiin sanaksi avustaja, koska Suomessa koulussa ei ole valmentajia). Lisäksi osaa arviointiasteikoista tarkennettiin. Englanninkielisessä versiossa alakouluikäisten lomakkeen yleiset tiedot kysymyksissä 5-9 ja nuorten kysymyksissä 6-10 viisiportaista arviointiasteikkoa kuvattiin kolmella määreellä "alot", "some" ja "nothing", jolloin kahdelle vastausvaihtoehdolle ei ollut sanallista määritelmää. Tässä tutkimuksessa arviointiasteikko tarkennettiin viisiportaiseen muotoon "hyvin paljon", "pal- jon", "jonkin verran", "vähän", "en mitään".

Jokainen OASES-itsearviointilomake koostuu neljästä erillisestä, mutta toisiinsa yhteydessä olevasta osasta. Osat ovat yleiset tiedot änkytyksestä, reaktiot änkytykseen, kommunikointi arkitilanteissa ja elämänlaatu. Alakouluikäisten OASES-S:ssä on 60 kysymystä, nuorten OASES-T:ssä 80 kysymystä ja aikuisten OASES-A:ssa 100 kysymystä, jotka arvioidaan viisiportaisella (1-5) Likertasteikolla. Mitä suuremman arvon puhuja valitsee, sitä kielteisemmäksi hän kokee änkytyksen vaikutuksen elämänlaatuunsa. Jokaiselle osalle (yleistiedot, reaktiot änkytykseen, kommunikointi arkitilanteissa, elämänlaatu) lasketaan änkytyksen vaikutusta kuvaava pistemäärä. Pistemäärä saadaan jakamalla vastausten yhteenlaskettu pistemäärä vastausten lukumäärällä. Vastausten lukumäärä saattaa olla eri kuin lomakkeessa olevien kysymysten määrä, sillä kunkin eri ikäryhmän vastauslomakkeessa on kysymyksiä, jotka eivät koske kaikkia vastaajia (esimerkiksi veljien ja siskojen kanssa puhumisen vaikeus, jos vastaajalla ei ole sisaruksia). Tällöin vastaus jätetään pisteyttämättä eikä kysymystä lasketa mukaan vastattujen kysymysten määrään. Jokaisen erillisen osan sekä yhteenlasketun kokonaispistemäärän perusteella määrittyy, kuinka suuri vaikutus änkytyksellä on henkilön elämään (Yaruss \& Quesal, 2016, taulukko 4). 
TAULUKKO 4. Vaikutusta kuvaava pistemäärä ja pistemäärään perustuva vaikutuksen luokitus suomeksi ja englanniksi (Yaruss \& Quesal, 2016).

\begin{tabular}{ll}
\hline Vaikutuksen luokitus & Vaikutusta kuvaava pistemäärä \\
\hline Lievä (mild) & $1,00-1,49$ \\
Lievä/keskivaikea (mild-moderate) & $1,50-2,24$ \\
Keskivaikea (moderate) & $2,25-2,99$ \\
Keskivaikea/vaikea (moderate-severe) & $3,00-3,74$ \\
Vaikea (severe) & $3,75-5,00$ \\
\hline
\end{tabular}

\subsection{Aineiston keruu}

Ennen tutkimusaineiston keruun aloittamista tutkimusprojektin johtaja lähetti sähköisesti kaikille tutkimusaineistoa kokoaville puheterapeuteille kirjallista tietoa tutkimusprojektista ja sen toteutuksesta. Aineiston kokoamiseen suostuneille henkilöille toimitettiin sähköisesti ohjeistus aineiston keräämisestä sekä tutkittaville annettavat tiedotteet, esitietolomakkeet, suostumusasiakirjat, suomenkieliset arviointilomakkeet sekä niiden pisteytysohjeet. Jos tutkittava kävi puheterapiassa, puheterapeuttia ohjeistettiin välttämään kommunikointiasenteiden käsittelyä tämän tutkimuksen alku- ja uusintamittauksen välisenä aikana. Alku- ja uusintamittauksen välinen aika oli noin viikko, joten tästä menettelystä ei katsottu olevan haittaa kuntoutukselle.

OASES-lomakkeisiin vastaajille, alakouluikäisten lasten osalta myös heidän vanhemmilleen, kerrottiin suullisesti tutkimuksesta. He saivat myös luettavaksi kullekin ikäryhmälle suunnatut tiedotteet, esitietolomakkeet sekä suostumusasiakirjan, jossa he vahvistivat halukkuutensa osallistua tutkimukseen ja antoivat luvan saatujen vastausten luovuttamisesta anonyymisti tutkijan käyttöön. Aikuiset täyttivät lomakkeet itse. Lasten vanhemmat täyttivät lapsia koskevat lomakkeet joko itse tai yhdessä lapsensa kanssa. Tutkimukseen osallistuminen oli vapaaehtoista, ja tutkittava sai halutessaan keskeyttää siihen osallistumi- sen tai kieltää vastaustensa tutkimuskäytön missä vaiheessa tahansa.

Aineiston kokoamiseen osallistunut puheterapeutti kävi testiin kuuluvan ohjeistuksen läpi suullisesti alakouluikäisten lasten kanssa. Lapset saivat kysyä apua puheterapeutilta, mikäli he eivät ymmärtäneet kysymystä. Kysymyksiin vastaamista ei ohjattu tai autettu. Nuoret ja aikuiset täyttivät lomakkeet itsenäisesti OASES-lomakkeissa olevien ohjeiden avulla. Tutkimusaineiston kokoamiseen osallistuneet puheterapeutit lähettivät vastauslomakkeet ilman tunnistetietoja tutkimusprojektin johtajalle tai tallensivat keräämänsä vastaukset ilman tunnistetietoja heille ennalta toimitettuun Excel-tiedostoon, jonka he toimittivat sähköisesti projektin johtajalle. Projektin johtaja kokosi saamansa vastaukset ja tiedostot yhteen tilastollisia analyysejä varten.

Toistomittausreliabiliteetin määrittämistä varten 11 alakouluikäistä lasta, 14 nuorta ja 9 aikuista täyttivät lomakkeen uudelleen viikon sisällä ensimmäisestä vastauskerrasta. Toistomittauskerralla saatuja vastauksia käytettiin ainoastaan uudelleenmittausreliabiliteetin arviointiin.

\subsection{Aineiston analysointi}

Tutkittavien antamat vastaukset pisteytettiin alkuperäisillä pisteytysohjeilla (Yaruss \& 
Quesal, 2016). Lomakkeissa oli ainoastaan yksittäisiä tyhjiä vastauksia, jotka sijaitsivat satunnaisesti eri tutkittavien eri kysymyksissä. Tyhjät vastaukset huomioitiin haittapistemääriä laskettaessa. Kunkin kysymyksen pisteet, neljän eri osan (yleistiedot, reaktiot änkytykseen, kommunikointi arkitilanteissa, elämänlaatu) kokonaispistemäärät sekä haittavaikutuksen pistemäärä tallennettiin IBM SPSS 25-tiedostoiksi aineistojen tilastollista analysointia varten.

Suomenkielisten OASES-S:n, OASEST:n ja OASES-A:n itsearviointimittareiden deskriptiiviset tunnusluvut laskettiin, jotta niitä voidaan verrata alkuperäisiin englanninkielisiin tunnuslukuihin ja tukemaan tilastollisten menetelmien valintaa (taulukko 4). Ulkoista validiteettia tutkittiin arvioimalla taustamuuttujan ikä yhteyttä kunkin mittarin kokonaisvaikutusta kuvaavaan pistemäärään käyttämällä parametrista Pearsonin tulomomenttikorrelaatiokerrointa, sillä muuttujat olivat jatkuvia. Parametrista Pearsonin tulomomenttikorrelaatiokerrointa käytettiin myös tutkittaessa OASES-itsearviointilomakkeiden rakennevaliditeettia, jossa arvioitiin kunkin mittarin osan (yleistiedot, reaktiot änkytykseen, kommunikointi arkitilanteissa, elämänlaatu) yhteyttä toisiinsa ja kokonaisvaikutusta kuvaavaan pistemäärään, sillä myös nämä muuttujat olivat jatkuvia. Sisällön validiteettia tutkittiin deskriptiivisesti vertaamalla suomenkielisten itsearviointilomakkeiden eri osien kokonaispistemäärien tilastollisia tunnuslukuja (keskiarvo ja hajonta) testien normituksessa käytettyihin, englanninkielisillä lomakkeilla saatuihin tunnuslukuihin, sillä käytettävissä oli ainoastaan normituksesta ilmoitetut kokonaispistemäärien tunnusluvut. Lisäksi verrattiin toisiinsa itsearvioinnin kokonaisvaikutuspistemäärään perustuvien luokitusten prosentuaalista jakaumaa suomenkielisillä ja englanninkielisillä mittareilla.

Kyselylomakkeiden sisäistä konsistenssia arvioitiin Cronbachin alfakertoimella. Toistomittausreliabiliteetin arvioimiseen käytettiin parametrista Pearsonin tulomomenttikorrelaatiokerrointa, koska kokonaispisteiden huipukkuus ja vinous osoittivat aineiston noudattavan normaalijakaumaa (taulukko 5). Tilastollisen merkitsevyyden rajaksi asetettiin $\mathrm{p}<0,05$.

TAULUKKO 5. Änkytyksen kokonaisvaikutusta kuvaava vaikutuspistemäärä.

\begin{tabular}{lcccccccc}
\hline & $\min$ & $\max$ & $\mathbf{k a}$ & $\mathbf{k h}$ & Mediaani & Moodi & Vinous & Huipukkuus \\
\hline $\begin{array}{l}\text { OASES-S } \\
\mathbf{n = 6 0}\end{array}$ & 1,52 & 3,43 & 2,28 & 0,51 & 2,17 & 1,90 & 0,58 & $-0,54$ \\
$\begin{array}{l}\text { OASES-T } \\
\mathbf{n = 3 1}\end{array}$ & 1,49 & 3,45 & 2,43 & 0,53 & 2,39 & 3,09 & 0,14 & $-0,84$ \\
$\begin{array}{l}\text { OASES-A } \\
\mathbf{n = 3 1}\end{array}$ & 1,20 & 3,68 & 2,52 & 0,63 & 2,37 & 2,38 & 0,02 & $-0,89$ \\
\hline
\end{tabular}

$\min =\operatorname{minimi} ; \max =$ maksimi $; \mathrm{ka}=$ keskiarvo; $\mathrm{kh}=$ keskihajonta 


\section{TULOKSET}

Tutkimustulokset osoittivat, että suomennettujen OASES-S:n, OASES-T:n ja OASESA:n pätevyys ja luotettavuus olivat hyvät. Tämä tulos on yhdenmukainen aiempien OASES-käännöstutkimusten havaintojen kanssa (Koedoot ym., 2011; Lankman ym., 2015; Lindström ym., 2020; Sakai ym., 2017).

\subsection{Suomennosten validiteetti}

Suomennettujen OASES-itsearviointilomakkeiden ulkoista validiteettia arvioitiin mittaamalla taustamuuttujan ikä yhteyttä kunkin mittarin kokonaisvaikutusta kuvaavaan pistemäräään. Tutkimustulos osoitti, että ikä ei ollut yhteydessä alakouluikäisten $\left(\mathrm{r}_{\mathrm{p}}=-0,51\right.$, $p=0,700)$, nuorten $\left(\mathrm{r}_{\mathrm{p}}=0,37, p=0,842\right)$ tai aikuisten $\left(\mathrm{r}_{\mathrm{p}}=0,158, p=0,395\right)$ itsearvioinnin pistemäärän. Näin ollen suomennetut OASES-S-, OASES-T- ja OASES-A-itsearviointilomakkeet mittaavat iästä riippumatta pätevästi änkyttävän henkilön kokemuksia änkytyksestä hänen omasta näkökulmastaan. Rakennevaliditeettia tutkittiin laskemalla Pearsonin tulomomenttikorrelaatiokerrointa käyttäen OASES-itsearviointilomakkeiden neljän eri osan (yleiset tiedot, reaktiot änkytykseen, kommunikointi arkitilanteissa, elämänlaatu) yhteyttä toisiinsa sekä niiden yhteyttä kokonaisvaikutusta kuvaavaan pistemäärään. Tutkimustulos osoitti tilastollisesti merkitsevän korrelaation kaikkien eri osien ja kokonaisvaikutusta kuvaavan pistemäärän välillä eri ikäryhmien itsearviointilomakkeiden pistemäärissä (taulukot 6-8) lukuun ottamatta nuorten yleiset tiedot (osa I) ja kommunikointi arkitilanteissa (osa III) -osien välillä (taulukko 6). Yarussin ja Quesalin (2016) mukaan tulos on odotusten mukainen, sillä henkilön kokemukseen omasta änkytyksestään vaikuttavat lukuisat eri tekijät.

TAULUKKO 6. OASES-S-itsearviointilomakkeen eri osien (kysymysten määrä suluissa) ja kokonaisvaikutuksen väliset korrelaatiot alakouluikäisillä.

\begin{tabular}{|l|l|l|l|l|}
\hline Osa & $\begin{array}{l}\text { Osa I } \\
\text { Yleiset tiedot } \\
(\mathbf{1 5 )}\end{array}$ & $\begin{array}{l}\text { Osa II } \\
\text { Reaktiot } \\
\text { änkytykseen } \\
\mathbf{( 2 0 )}\end{array}$ & $\begin{array}{l}\text { Osa III } \\
\text { Kommunikointi } \\
\text { arkitilanteissa } \\
\mathbf{( 1 5 )}\end{array}$ & $\begin{array}{l}\text { Osa IV } \\
\text { Elämänlaatu } \\
\mathbf{( 1 0 )}\end{array}$ \\
\hline $\begin{array}{l}\text { Osa II } \\
\text { Reaktiot } \\
\text { änkytykseen }\end{array}$ & $0,40^{* * *}$ & & & \\
\hline $\begin{array}{l}\text { Osa III } \\
\text { Kommunikointi } \\
\text { arkitilanteissa }\end{array}$ & $0,47^{* * *}$ & $0,72^{* * *}$ & $0,67^{* * *}$ & \\
\hline $\begin{array}{l}\text { Osa IV } \\
\text { Elämänlaatu }\end{array}$ & $0,40^{*}$ & $0,60^{*}$ & $0,85^{* *}$ & $0,73^{* *}$ \\
\hline $\begin{array}{l}\text { Kokonais. } \\
\text { vaikutus }\end{array}$ & $0,63^{* * *}$ & $0,89^{* *}$ & & \\
\hline
\end{tabular}

${ }^{* *} p<0,01,{ }^{*} p<0,05$ 
TAULUKKO 7. OASES-T-itsearviointilomakkeen eri osien (kysymysten määrä suluissa) ja kokonaisvaikutuksen väliset korrelaatiot nuorilla.

\begin{tabular}{|l|l|l|l|l|}
\hline Osa & $\begin{array}{l}\text { Osa I } \\
\text { Yleiset tiedot }\end{array}$ & $\begin{array}{l}\text { Osa II } \\
\text { Reaktiot } \\
\text { änkytykseen } \\
\mathbf{( 2 5 )}\end{array}$ & $\begin{array}{l}\text { Osa III } \\
\text { Kommunikointi } \\
\text { arkitilanteissa } \\
\mathbf{( 2 0 )}\end{array}$ & $\begin{array}{l}\text { Osa IV } \\
\text { Elämänlaatu }\end{array}$ \\
\hline $\begin{array}{l}\text { Osa II } \\
\text { Reaktiot } \\
\text { änkytykseen }\end{array}$ & $0,42^{*}$ & & (20) \\
\hline $\begin{array}{l}\text { Osa III } \\
\text { Kommunikointi } \\
\text { arkitilanteissa }\end{array}$ & 0,18 & $0,61^{* *}$ & $0,68^{* *}$ & \\
\hline $\begin{array}{l}\text { Osa IV } \\
\text { Elämänlaatu }\end{array}$ & $0,37^{*}$ & $0,71^{* *}$ & $0,81^{* *}$ & $0,90^{* *}$ \\
\hline $\begin{array}{l}\text { Kokonais- } \\
\text { vaikutus }\end{array}$ & $0,53^{* *}$ & $0,90^{* *}$ & & \\
\hline
\end{tabular}

${ }^{* *} p<0,01,{ }^{*} p<0,05$

TAULUKKO 8. OASES-A-itsearviointilomakkeen eri osien (kysymysten määrä suluissa) ja kokonaisvaikutuksen väliset korrelaatiot aikuisilla.

\begin{tabular}{|l|l|l|l|l|}
\hline Osa & $\begin{array}{l}\text { Osa I } \\
\text { Yleiset tiedot }\end{array}$ & $\begin{array}{l}\text { Osa II } \\
\text { Reaktiot } \\
\text { änkytykseen } \\
\mathbf{( 3 0 )}\end{array}$ & $\begin{array}{l}\text { Osa III } \\
\text { Kommunikointi } \\
\text { arkitilanteissa } \\
\mathbf{( 2 5 )}\end{array}$ & $\begin{array}{l}\text { Osa IV } \\
\text { Elämänlaatu }\end{array}$ \\
\hline $\begin{array}{l}\text { Osa II } \\
\text { Reaktiot } \\
\text { änkytykseen }\end{array}$ & $0,67^{* *}$ & & & \\
\hline $\begin{array}{l}\text { Osa III } \\
\text { Kommunikointi } \\
\text { arkitilanteissa }\end{array}$ & $0,48^{* *}$ & $0,78^{* *}$ & $0,70^{* *}$ & \\
\hline $\begin{array}{l}\text { Osa IV } \\
\text { Elämänlaatu }\end{array}$ & $0,54^{* *}$ & $0,82^{* * *}$ & $0,87^{* *}$ & $0,90^{* *}$ \\
\hline $\begin{array}{l}\text { Kokonais- } \\
\text { vaikutus }\end{array}$ & $0,71^{* *}$ & $0,95^{* *}$ & & \\
\hline
\end{tabular}

${ }^{* *} p<0,01,{ }^{*} p<0,05$

Sisällön validiteettia arvioitiin vertaamalla deskriptiivisesti suomennettujen OASESitsearviointilomakkeiden tilastollisia tunnuslukuja alkuperäisiin englanninkielisiin tunnuslukuihin. Suomenkielisten ja englanninkielisten itsearviointien keskiarvot eri ikäryhmillä olivat samankaltaiset (taulukot 9-11). Keskiarvoissa suurimmat erot olivat yleiset tiedot osassa alakouluikäisillä $(0,20$ p) ja nuorilla $(0,17$ p) sekä kommunikointi arkitilanteissa osassa aikuisilla (0,18 p). Suomalaisten itsearviointien hajonta oli jonkin verran suurempaa lähes kauttaaltaan verrattuna alkuperäisillä itsearviointilomakkeilla saatuihin tuloksiin. 
TAULUKKO 9. Suomennetun ja alkuperäisten englanninkielisten OASES-S-itsearviointilomakkeen vaikutusta kuvaaviin pistemääriin perustuvat deskriptiiviset tunnusluvut.

\begin{tabular}{|l|l|l|l|l|}
\hline & \multicolumn{2}{|l|}{$\begin{array}{l}\text { Suomenkielinen } \\
\text { OASES-S }\end{array}$} & \multicolumn{2}{l|}{$\begin{array}{l}\text { Englanninkielinen } \\
\text { OASES-S }\end{array}$} \\
\hline & ka & kh & ka & kh \\
\hline I Yleiset tiedot & 2,77 & 0,48 & 2,57 & 0,48 \\
\hline II Reaktiot änkytykseen & 2,34 & 0,76 & 2,38 & 0,41 \\
\hline III Kommunikointi arkitilanteissa & 2,00 & 0,58 & 2,08 & 0,49 \\
\hline IV Elämänlaatu & 1,73 & 0,57 & 1,72 & 0,23 \\
\hline Kokonaisvaikutus & 2,28 & 0,51 & 2,25 & 0,50 \\
\hline
\end{tabular}

$\mathrm{ka}=$ keskiarvo, $\mathrm{kh}=$ keskihajonta

TAULUKKO 10. Suomennetun ja alkuperäisten englanninkielisten OASES-T-itsearviointilomakkeen vaikutusta kuvaaviin pistemääriin perustuvat deskriptiiviset tunnusluvut.

\begin{tabular}{|l|l|l|l|l|}
\hline & \multicolumn{2}{|l|}{$\begin{array}{l}\text { Suomenkielinen } \\
\text { OASES-T }\end{array}$} & \multicolumn{2}{l|}{$\begin{array}{l}\text { Englanninkielinen } \\
\text { OASES-T }\end{array}$} \\
\hline & ka & kh & ka & kh \\
\hline I Yleiset tiedot & 2,83 & 0,52 & 2,66 & 0,34 \\
\hline II Puhujan reaktiot änkytykseen & 2,59 & 0,66 & 2,54 & 0,41 \\
\hline III Kommunikointi arkitilanteissa & 2,36 & 0,65 & 2,30 & 0,35 \\
\hline IV Elämänlaatu & 2,02 & 0,72 & 1,92 & 0,28 \\
\hline Kokonaisvaikutus & 2,43 & 0,53 & 2,40 & 0,70 \\
\hline
\end{tabular}

ka = keskiarvo, $\mathrm{kh}=$ keskihajonta

TAULUKKO 11. Suomennetun ja alkuperäisten englanninkielisten OASES-A-itsearviointilomakkeen vaikutusta kuvaaviin pistemääriin perustuvat deskriptiiviset tunnusluvut.

\begin{tabular}{|l|l|l|l|l|}
\hline & \multicolumn{2}{l|}{$\begin{array}{l}\text { Suomenkielinen } \\
\text { OASES-A }\end{array}$} & \multicolumn{2}{l|}{$\begin{array}{l}\text { Englanninkielinen } \\
\text { OASES-A }\end{array}$} \\
\hline & ka & kh & ka & kh \\
\hline I Yleiset tiedot & 2,62 & 0,62 & 2,67 & 0,32 \\
\hline II Puhujan reaktiot änkytykseen & 2,69 & 0,68 & 2,73 & 0,41 \\
\hline III Kommunikointi arkitilanteissa & 2,43 & 0,69 & 2,61 & 0,43 \\
\hline IV Elämänlaatu & 2,34 & 0,80 & 2,32 & 0,39 \\
\hline Kokonaisvaikutus & 2,52 & 0,63 & 2,60 & 0,74 \\
\hline
\end{tabular}

$\mathrm{ka}=$ keskiarvo, $\mathrm{kh}=$ keskihajonta 
Änkytyksen vaikutukseen perustuva luokitus (lievä, lievä/keskivaikea, keskivaikea, keskivaikea/vaikea, vaikea änkytys) perustuu vastaajan saamaan kokonaispistemäärään (1,0-5,0 pistettä) (kuviot 1-3). Kaikkien ikäluokkien suomenkieliset itsearvioinnit painottuivat pääasiassa kolmeen keskimmäiseen vaikutusluokkaan (lievä/ keskivaikea, keskivaikea ja keskivaikea/ vaikea), kun taas äärimmäisiin luokkiin (lievä, vaikea) määrittyi vähän, jopa ei yhtään itsearviointia. Sen sijaan alkuperäisen englanninkielisen itsearvioinnin tulosten mukaan kaikkiin vaikeusastetta kuvaaviin luokkiin sijoittui osa vastauksista.

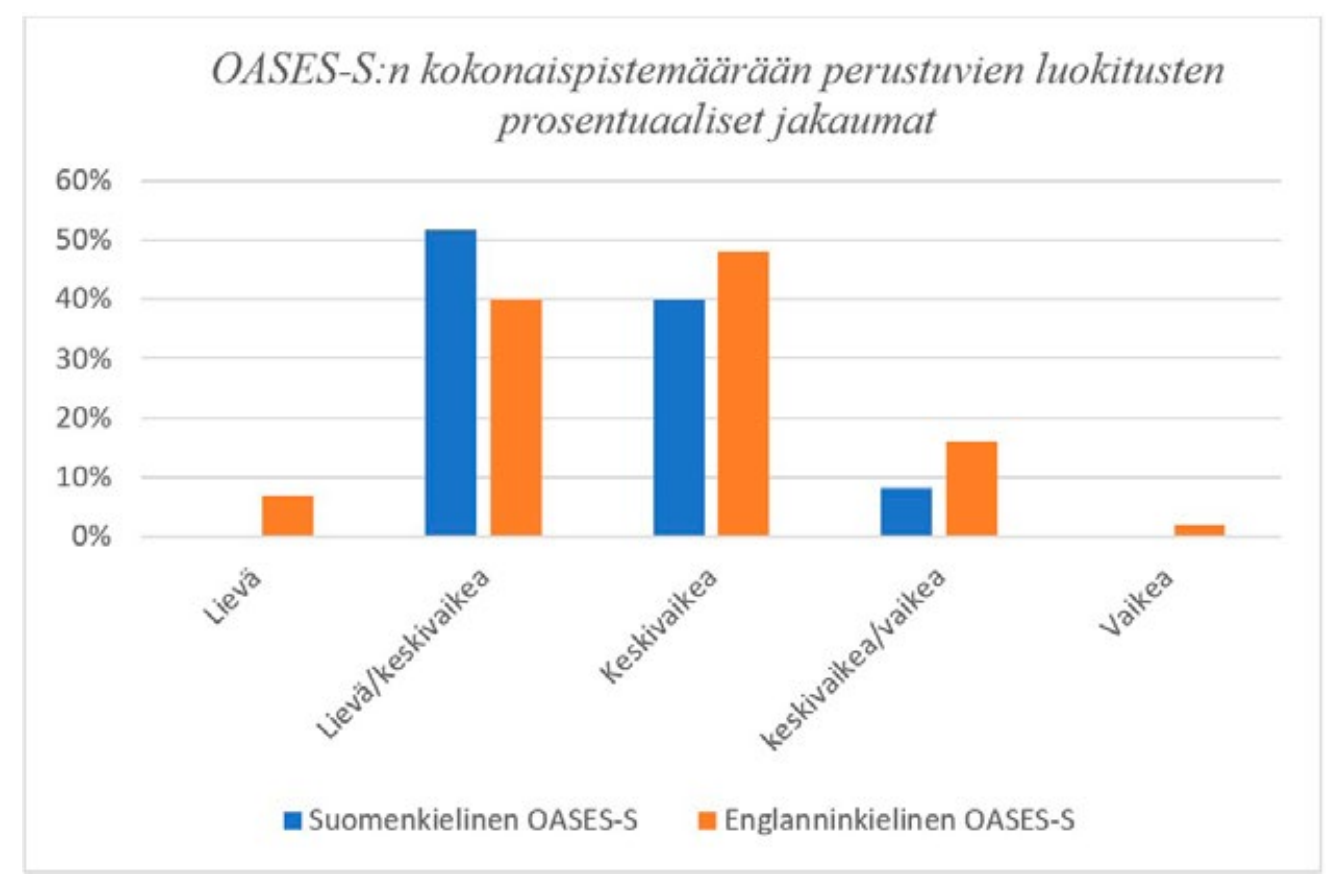

KUVIO 1. Suomenkielisen ja englanninkielisen OASES-S:n itsearviointiin perustuvien luokitusten prosentuaaliset jakaumat alakouluikäisillä. 


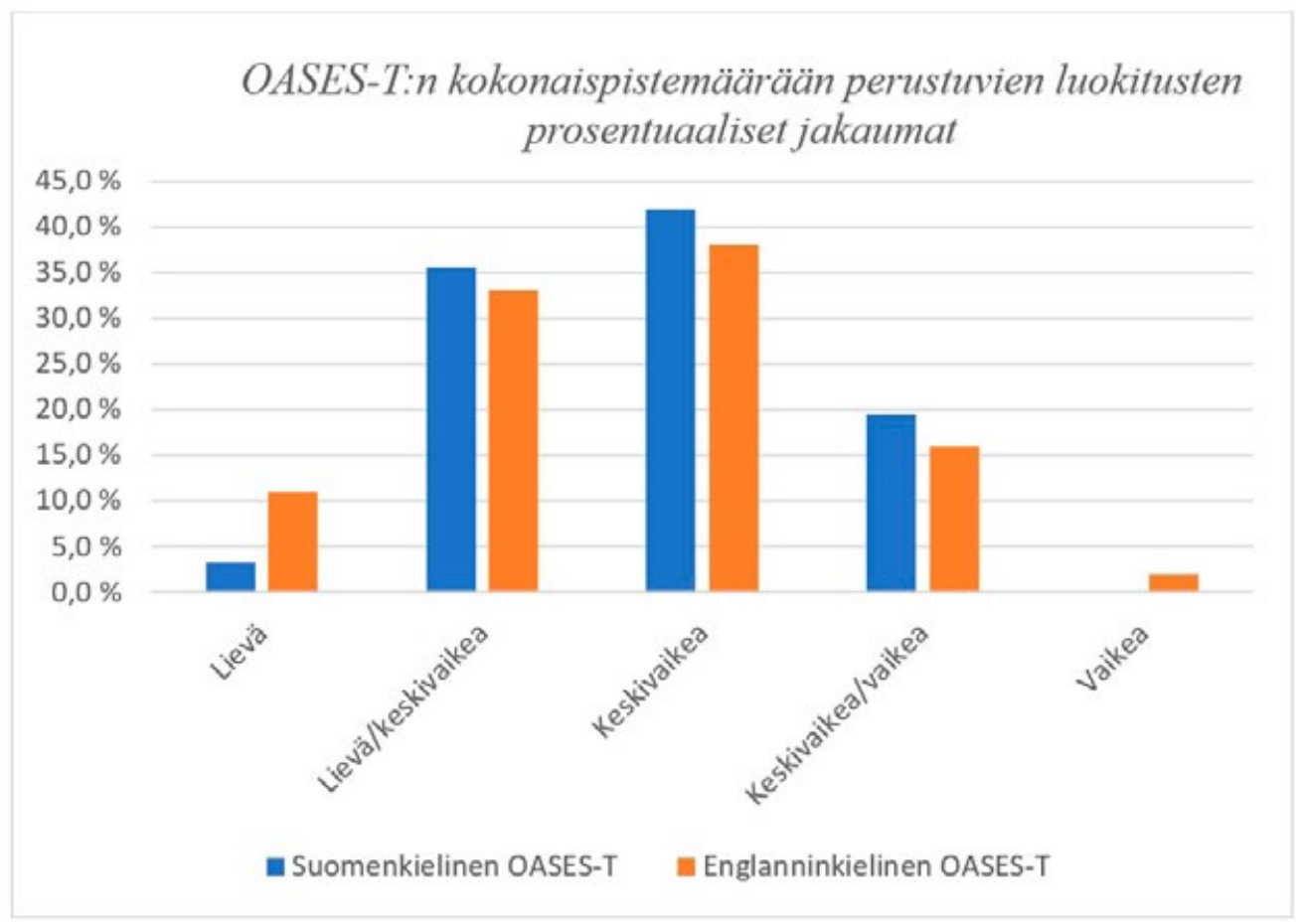

KUVIO 2. Suomenkielien ja englanninkielien OASES-T:n itsearviointiin perustuvien luokitusten prosentuaaliset jakaumat nuorilla.

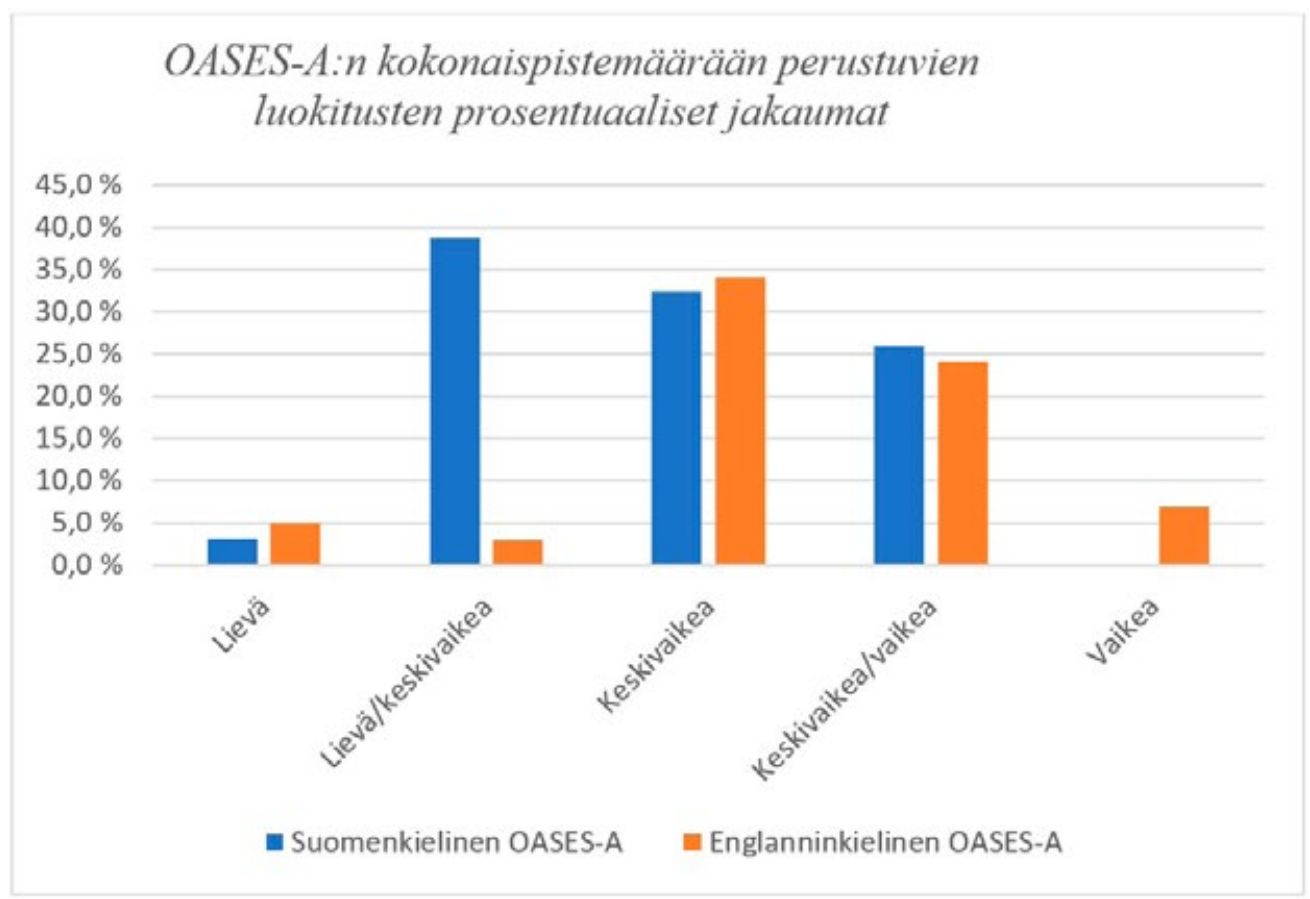

KUVIO 3. Suomenkielien ja englanninkielien OASES-A:n itsearviointiin perustuvien luokitusten prosentuaaliset jakaumat aikuisilla. 


\subsection{Suomennosten reliabiliteetti}

OASES-itsearviointien reliabiliteettia tarkasteltiin sekä sisäisenä konsistenssina (Cronbachin alfa) että toistomittausreliabiliteettina (korrelaatiokerroin). Alakouluikäisten OASES-S-mittarin sisäinen konsistenssi havaittiin hyväksi $(\alpha=0,85-0,91$, taulukko 12). Myös nuorten $(\alpha=0,81-0,92$; taulukko 12) ja aikuisten ( $\alpha=0,90-0,95$; taulukko 12$)$ OASES-itsearviointilomakkeiden sisäinen konsistenssi osoittautui hyväksi.

TAULUKKO 12. Eri ikäisille suunnattujen OASES-itsearviointilomakkeiden sisäinen yhtenäisyys.

\begin{tabular}{|l|l|l|l|l|l|}
\hline & $\begin{array}{l}\text { Osa I } \\
\text { Yleiset tiedot } \\
\alpha\end{array}$ & $\begin{array}{l}\text { Osa II } \\
\text { Reaktiot } \\
\text { änkytykseen } \\
\alpha\end{array}$ & $\begin{array}{l}\text { Osa III } \\
\text { Kommuni- } \\
\text { kointi arki- } \\
\text { tilanteissa } \\
\alpha\end{array}$ & $\begin{array}{l}\text { Osa IV } \\
\text { Elämänlaatu } \\
\alpha\end{array}$ & $\begin{array}{l}\text { Kokonais- } \\
\text { vaikutus } \\
\alpha\end{array}$ \\
\hline $\begin{array}{l}\text { OASES-S } \\
\mathbf{n = 6 0}\end{array}$ & 0,91 & 0,87 & 0,85 & 0,88 & 0,82 \\
\hline $\begin{array}{l}\text { OASES-T } \\
\mathbf{n}=\mathbf{3 1}\end{array}$ & 0,92 & 0,84 & 0,87 & 0,84 & 0,81 \\
\hline $\begin{array}{l}\text { OASES-A } \\
\mathbf{n}=\mathbf{3 1}\end{array}$ & 0,95 & 0,90 & 0,93 & 0,92 & 0,89 \\
\hline
\end{tabular}

OASES-itsearviointilomakkeiden mittaustulosten pysyvyyttä arvioitiin vertaamalla ensimmäisen ja toisen mittauskerran tuloksia toisiinsa. Tulokset osoittivat, että ryhmien ensimmäisen ja toisen mittauskerran itsearvioin- tien kokonaispistemäärät olivat tilastollisesti merkitsevästi yhteydessä toisiinsa $(\mathrm{p}<0,01$ tai $\mathrm{p}<0,05)$ kaikkien lomakkeiden ja kaikkien osien osalta lukuun ottamatta OASES-A:n yleiset tiedot -osaa (taulukko 13).

TAULUKKO 13. OASES-itsearviointilomakkeiden toistomittauksen reliabiliteetti alakouluikäisillä $(n=12)$, nuorilla $(n=14)$ ja aikuisilla $(n=10)$.

\begin{tabular}{|l|l|l|l|l|l|}
\hline & $\begin{array}{l}\text { Osa I } \\
\text { Yleiset tiedot }\end{array}$ & $\begin{array}{l}\text { Osa II } \\
\text { Reaktiot } \\
\text { änkytykseen }\end{array}$ & $\begin{array}{l}\text { Osa III } \\
\text { Kommuni- } \\
\text { kointi arki- } \\
\text { tilanteissa }\end{array}$ & $\begin{array}{l}\text { Osa IV } \\
\text { Elämänlaatu }\end{array}$ & $\begin{array}{l}\text { Kokonais- } \\
\text { vaikutus }\end{array}$ \\
\hline OASES-S & $0,78^{* *}$ & $0,76^{* *}$ & $0,70^{*}$ & $0,83^{* *}$ & $0,96^{* *}$ \\
\hline OASES-T & $0,60^{*}$ & $0,66^{* *}$ & $0,65^{*}$ & $0,84^{* *}$ & $0,60^{*}$ \\
\hline OASES-A & 0,16 & $0,85^{* *}$ & $0,72^{*}$ & $0,97^{* *}$ & $0,88^{* *}$ \\
\hline
\end{tabular}

${ }^{* *} p<0,01,{ }^{* *} p<0,05$ 


\section{POHDINTA}

Änkytys voi vaikuttaa ihmisen puheeseen, kommunikointikykyyn ja elämänlaatuun monella eri tavalla. Siitä syystä pelkästään puheessa esiintyvien sujumattomuuksien arvioiminen ei ole riittävää änkytystä arvioitaessa. Overall Assessment of the Speaker's Experience of Stuttering (OASES区; Yaruss \& Quesal, 2016) -itsearviointimenetelmä mittaa kokemuksia änkytyksestä änkyttävän henkilön omasta näkökulmasta. Ihmisen kokemuksia ei voi ilmaista kukaan muu kuin ihminen itse, ja siksi itsearviointilomakkeet ovat merkittäviä mittareita kokonaiskuvan saamiseksi (Leith ym., 1993; O'Brian ym., 2020).

Tämän tutkimuksen tavoitteena oli arvioida englannin kielestä suomen kieleen käännettyjen ja Suomen kulttuuriin mukautettujen alakouluikäisten, nuorten ja aikuisten OASES-itsearviointilomakkeiden suomennosten validiteettia ja reliabiliteettia. Tutkimustuloksemme osoittivat, että sekä alakouluikäisille suunnattu OASES-S-, nuorille suunnattu OASES-T- että aikuisille suunnattu OASES-A-itsearviointilomake arvioivat luotettavasti henkilöiden kokemuksia änkytyksen vaikutuksesta heidän elämäänsä änkyttävän henkilön omasta näkökulmasta.

Käännöksien validiteettia tarkasteltiin arvioimalla taustamuuttujan ikä yhteyttä henkilöiden saamiin pistemääriin, vertaamalla, voidaanko mittarin eri osien (yleiset tiedot, reaktiot änkytykseen, kommunikointi arkitilanteissa ja elämänlaatu) välillä havaita yhteyttä sekä vertaamalla deskriptiivisesti tässä tutkimuksessa saatuja arvoja alkuperäisiin englanninkielisiin viitearvoihin. Tutkimustulos osoitti, että OASES-itsearviointilomakkeet erottelevat pätevästi ihmisten kokemusta änkytyksen vaikutuksesta heidän elämäänsä iästä riippumatta. Myös OASES-itsearviointimittareiden rakennevaliditeetti todettiin hyväksi.
OASES-itsearviointimittareiden sisällön validiteettia tarkasteltiin vertaamalla vaikutuksen luokitusten prosentuaalisia jakaumia suomenkielisillä ja englanninkielisillä itsearviointimenetelmillä. Suomenkielisten ja englanninkielisten itsearviointien eri osien ja änkytyksen kokonaisvaikutusta kuvaavan pistemäärän keskiarvot ovat samankaltaiset. Alakouluikäisten OASES-S:n kokonaispistemäärä oli sama kuin ruotsinkielisen vastaavan ikäryhmän itsearvioinnin pistemäärä (Lindström ym., 2020), mutta hieman korkeampi kuin alkuperäisen amerikkalaisen, englanninkielisen (Yaruss \& Quesal, 2016) tai hollanninkielisen (Lankman ym., 2015) itsearvioinnin pistemäärä. Nuorten OASES$\mathrm{T}$ itsearvioinnin kokonaispistemäärä oli suomenkielisillä nuorilla hieman korkeampi kuin englanninkielisillä nuorilla saatu tulos (Yaruss \& Quesal, 2016), mutta alhaisempi kuin ruotsalaisten nuorten itsearvioinnin pistemäärä (Lindstöm ym., 2020). Aikuisten OASES-A:n kokonaispistemäärät olivat alhaisimmat ruotsin- (Lindström ym., 2020) ja hollanninkielisillä (Koedoot ym., 2011) ja korkeimmat japaninkielisillä (Sakai ym., 2017), suomenkielisen arvioinnin pistemäärän jäädessä edellisten väliin. Eri ikäisille suunnattujen ja eri kielisten mittareiden tulokset ovat kuitenkin hyvin samankaltaisia, joten eri ikäluokille suunnatuilla OASESitsearviointilomakkeilla saatuja tuloksia voi verrata yli kielirajojen, mistä syystä OASESitsearviointilomakkeet auttavat sekä kliinistä päätöksentekoa että tutkimusta. Itsearviointilomakkeiden avulla voidaan verrata mahdollisia muutoksia iän karttuessa. Lisäksi OASESitsearviointimittareilla saatuja suomenkielisiä tutkimustuloksia voi verrata muilla kielillä saatuihin tutkimustuloksiin.

Suomennettujen OASES-itsearviointimittareiden luotettavuus osoittautui hyväksi, sillä alfakertoimet olivat korkeat $(\alpha 0,81-0,95)$, kuten aiemmissakin tutkimuksissa on ha- 
vaittu (Koedoot ym., 2011; Sakai ym., 2017; Yaruss \& Quesal, 2016). Lisäksi alkumittauksen tulokset korreloivat merkitsevästi uusintamittauksen tulosten kanssa lukuun ottamatta OASES-A:n yleiset tiedot -osaa. Tämä tulos on samankaltainen kuin ruotsinkielisen OASES-A:n itsearvioinneista tehdyt havainnot (Lindström ym., 2020) mutta poikkeaa Sakain ym. (2017) sekä Yarussin ja Quesalin (2016) tutkimuksista, joissa myös osan I (yleiset tiedot) korrelaatiot kahden mittauskerran välillä olivat tilastollisesti merkitseviä. Tarkasteltaessa osan I yksittäisiin kysymyksiin vastaamista tässä tutkimuksessa, osoittautui, että ensimmäisellä kerralla vastaajat olivat käyttäneet koko arviointiasteikkoa yhdestä viiteen, kun taas toisella kerralla vastaukset rajoittuivat pääasiassa asteikolle kahdesta neljään. Syytä tällaiseen muutokseen on vaikea arvioida, sillä itsearviointilomakkeen uudelleen täyttäneiden aikuisten änkytyksen vaikeusaste vaihteli lievästä vaikeaan, vain osa oli saanut puheterapiaa ja vain osa oli mukana vertaistukiryhmässä. On mahdollista, että aikuiset ovat itsearviointilomakkeen ensimmäisen täyttämiskerran jälkeen jääneet pohtimaan kysymyksiä ja hakeneet lisätietoa kysymyksen aiheista, mikä voisi selittää muutoksen. Huolimatta aikuisten yleiset tiedot -osan alhaisesta uudelleenmittausreliabiliteetista, kokonaisvaikutusta kuvaavan pistemäärän alfakerroin oli korkea, mistä syystä voimme pitää OASES-itsearviointimenetelmää luotettavana mittarina arvioitaessa henkilön omaa kokemusta änkytyksen vaikutuksesta hänen elämänlaatuunsa.

Vaikka erikielisten itsearviointien änkytyksen kokonaisvaikutusta kuvaavat pistemäärät ja eri osien pistemäärien keskiarvot todettiin samankaltaisiksi, vaikeusasteluokitusten prosentuaaliset jakaumat erosivat englanninkielisistä jakaumista. Yksittäisten kysymysten vastauksia tarkasteltaessa ilmeni, että suomenkieliset vastaajat käyttivät vähän Likert- asteikon äärimmäisiä arvoja 1 ja 5 arvioinneissaan. Tämä mahdollisesti selittää änkytyksen vaikutusta kuvaavien luokitusten ääriarvojen (lievä ja vaikea) puuttumisen toisin kuin normituksessa käytetyssä englanninkielisissä itsearvioinneissa (Yaruss \& Quesal, 2016). Lankmannin ym. (2015) alakouluikäisten OASES-S:n itsearviointia käsittelevässä tutkimuksessa todettiin samansuuntaisesti, sillä yhdenkään lapsen itsearviointia ei luokiteltu ryhmään "vaikea”. Lankman ym. (2015) esittävät, että yksi syy tulokseen voi olla se, että kuntoutusta saaneet vastaajat olivat yliedustettuna tutkimusryhmässä, mikä on mahdollista myös tässä tutkimuksessa. Vastaajat ovat ehkä käsitelleet itsearviointilomakkeissa esitettyjä asioita omassa puheterapiassaan ja vertaistukiryhmissään, mistä syystä ainakin kaikkein negatiivisimmat kokemukset ovat lieventyneet. Toisaalta Lindström ym. (2020) esittävät, että vastaajan kulttuuritausta on yhteydessä siihen, miten henkilö kokee änkytyksen vaikuttavan elämäänsä. Myös ääriarvojen välttäminen arvioinneissa saattaa olla kulttuuriin liittyvä tekijä. Tarvitaan siis tutkimusta, jossa tarkastellaan kuntoutuksen ja kulttuurierojen mahdollista yhteyttä OASES-itsearviointilomakkeiden vaikutusta kuvaaviin pistemääriin OASES-itsearviointimenetelmän sensitiivisyyden parantamiseksi.

Alkuperäinen englanninkielinen vaikeusasteluokitus (esimerkiksi mild-moderate ja moderate-severe) ei vastaa suomalaista kliinistä käytännettä, jossa tavanomaisesti änkytyksen vaikeusaste luokitellaan viisiportaisesti erittäin lieväksi, lieväksi, keskivaikeaksi, vaikeaksi ja erittäin vaikeaksi. Terveydenhuollon ja kliininen käytänteen kannalta on täten aiheellista muuttaa suomenkielisten OASESlomakkeiden vaikeusasteluokitus vastaamaan Suomen käytänteitä.

Änkytyksen arviointiin on kansainvälisesti olemassa useita itsearviointimenetelmiä. OASES erottuu niiden joukossa monipuo- 
lisesti änkytyksen vaikutuksia kartoittavana menetelmänä. Viisiportainen vastausasteikko mahdollistaa esimerkiksi kuntoutuksen vaikutuksen havaitsemisen paremmin kuin osassa muista lomakkeista käytössä oleva dikotominen totta/väärin asteikko. OASES:n ohella myös UTBAS on laaja itsearviontikysely. Kliinisessä työssä OASES:n vahvuus on neutraaleissa kysymyksissä (esim. kuinka vaikeaa sinun on puhua esimiehesi kanssa), kun taas UTBAS lähtee negatiivisesta olettamuksesta (esim. en pysty pitämään työpaikkaani, jos änkytän). Vaikka UTBAS on laaja, sen kaikki kysymykset käsittelevät negatiivisia uskomuksia, kun taas OASES:n näkökulma on puhujan reaktioissa ja niiden vaikutuksissa arjen toimintakykyyn. OASES on toistaiseksi myös ainoa, laaja-alaisesti puhujan kokemuksia kartoittava kysely, jota on mahdollista käyttää seitsemän vuoden iästä aikuisuuteen asti.

OASES-itsearviointimenetelmä on kliinisessä puheterapiatyössä hyödyllinen arviointiväline, jolla saadaan laajasti ja eri näkökulmista tietoa änkytyksen vaikutuksista ihmisen elämään. OASES-itsearvioinnin avulla arvioinnin keskiöön nousevat asiakkaan kokemukset ja näkemykset änkytyksestä sekä änkytyksen herättämät kielteiset tunteet ja toimintatavat. OASES sopii käytettäväksi kuntoutustarvetta arvioitaessa sekä myös kuntoutuksen vaikuttavuutta seurattaessa. Se täydentää puheterapeutin tekemää arviointia ja havaintoja asiakkaan puhetilanteesta ja voi välillä nostaa selkeästi esille esimerkiksi sen, miten häiritsevänä lievältäkin kuulostava änkytys voi asiakkaan elämässä näyttäytyä. OASES saattaa myös saada asiakkaan ajattelemaan änkytystä aiempaa useammista näkökulmista ja laajentaa ymmärrystä siitä, millaisilla tavoilla änkytys eri elämäntilanteissa vaikuttaa. OASES-vastaukset toimivat kliinisessä työssä myös hyödyllisenä perustana puheterapiassa käytävälle keskustelle ja autta- vat puheterapeuttia suuntaamaan asiakkaalle lisää kysymyksiä asiakkaalle merkityksellisistä teemoista.

Suomennettujen ja Suomen kulttuuriin mukautettujen OASES-itsearviointilomakkeiden hyvä validiteetti ja reliabiliteetti mahdollistavat suomenkielisten, puheen sujuvuuden häiriöitä käsittelevien tutkimustulosten vertailun muun muassa englanninkielisiin tutkimuksiin. Kuten Lindström ym. (2020) ja Koedoot ym (2011) ovat havainneet, myös tässä tutkimuksessa ilmeni kuitenkin, että änkytyksen vaikutusta kuvaavaan pistemäärään perustuvien luokitusten prosentuaaliset osuudet poikkesivat englanninkielisistä luokituksista jossain määrin. Esimerkiksi vaikeaa änkytystä ei esiintynyt missään ikäluokassa toisin kuin englanninkielisillä itsearviointilomakkeilla saaduissa arvioinneissa. Alkuperäinen englanninkielinen luokitus perustuu laajaan tutkimusaineistoon, joten tarvitaan lisätutkimusta ennen kuin luokituksessa käytettyjen pistemäärien rajoja voidaan muuttaa eri kielille käännettyihin itsearviointilomakkeisiin.

Suomennetut itsearviointilomakkeet lähetettiin kokeneille, änkytyksen arviointiin perehtyneille puheterapeuteille yhdessä itsearviointilomakkeiden täyttöohjeiden kanssa. Täten kaikki puheterapeutit saivat saman ohjeistuksen. On kuitenkin mahdollista, että itsearviointilomakkeita täyttämisessä on ollut jotain eroavuuksia (esimerkiksi, täyttivätkö henkilöt lomakkeet kotona vai puheterapian yhteydessä). Tästä huolimatta itsearviointilomakkeiden validiteetti ja reliabiliteetti olivat hyvät, mikä vahvistaa edelleen itsearviointilomakkeiden luotettavuutta arvioitaessa henkilön omaa kokemusta änkytyksestään.

Itsearviointilomakkeet soveltuivat suurelta osin Suomen kulttuuriin. Suomen kulttuuriin mukauttaminen käsitti pääasiassa sopivien sanavalintojen ja ilmausten valintoja. Tällainen oli esimerkiksi ilmaisu "ruuan tilaaminen 
ajokaistalla", joka muutettiin ilmaisuksi "ruuan tilaaminen grillikioskilla", sillä kaikkialla Suomessa ei mahdollisesti ole ravintolaa, jossa ruokaa tilattaisiin ajokaistalta. Lisäksi esimerkiksi "teen-aged" käännettiin sanaksi nuori. Koekäytössä olleissa itsearviointilomakkeissa oli alkuperäisten itsearviointilomakkeiden mukaiset vaikeusasteluokitukset (esimerkiksi mild/moderate). Lopullisessa käännöksessä ne on syytä muuttaa viisiportaiseksi luokitukseksi, joka vastaa suomalaista kliinistä käytännettä (erittäin lievä, lievä, keskivaikea, vaikea, erittäin vaikea)

Yhteenvetona voidaan todeta, että suomennetut ja Suomen kulttuuriin mukautetut OASES-itsearviointilomakkeet arvioivat luotettavasti henkilöiden kokemuksia änkytyksen vaikutuksesta heidän elämäänsä heidän omasta näkökulmastaan. Tulevaisuudessa olisi aiheellista kansainvälisessä yhteistyössä pohtia vaikeusasteluokituksen pisterajoja itsearviointilomakkeiden sensitiivisyyden parantamiseksi.

\section{KIITOKSET}

Haluamme kiittää kaikkia lapsia ja nuoria, heidän vanhempiaan sekä aikuisia, jotka vapaaehtoisesti osallistuivat tähän tutkimukseen. Lisäksi kiitämme puheterapeutteja, jotka osallistuivat käännösten arviointiin, ja jotka auttoivat änkyttävien lasten, nuorten ja aikuisten aineiston kokoamisessa kiireisen kliinisen työnsä lomassa. Kiitämme myös logopedian opiskelijoita (Outi Laitinen, Leena Mäntylä ja Usva Vahanne), jotka tekivät ensimmäiset käännökset ja koekäyttivät niiden toimivuutta opinnäytetyönään. Ilman teidän kaikkien apua tutkimuksemme ei olisi ollut mahdollista. 


\section{LÄHTEET}

Andrews, G. \& Cutler, J. (1974). Stuttering therapy: The relation between changes in symptom level and attitudes. Journal of Speech and Hearing Disorders, 39, 312-319. https:// doi.org/10.1044/jshd.3903.312

Bloodstein, O. \& Ratner, N. B. (2008). A handbook on stuttering. Thomson/Delmar Learning.

Blumgart, E., Tran, Y., Yaruss, J. S. \& Craig, A. (2012). Australian normative data for the Overall Assessment of the Speaker's Experience of Stuttering. Journal of Fluency Disorders, 37, 83-90. https://doi.org/10.1016/j. jfludis.2011.12.002

Brutten, G. \& Dunham, S. (1989). The Communication Attitude Test: A normative study of grade school children. Journal of Fluency Disorders, 14, 371-377. https://doi. org/10.1016/0094-730X(89)90017-X

Choi, D., Conture, E., Tumanova,V., Clark, C., Walden, T. \& Jones, R. (2018). Young children's family history of stuttering and their articulation, language and attentional abilities: An exploratory study. Journal of Communication Disorders, 71, 22-36. https:// doi.org/10.1016/j.jcomdis.2017.11.002

Conture, E. G. (2001). Stuttering: Its nature, diagnosis, and treatment. Allyn \& Bacon.

Daniels, E.D., Gabel, R.M. \& Hughes, S. (2012). Recounting the K-12 school experiences of adults who stutter: A qualitative analysis. Journal of Fluency Disorders, 37, 71-82. https:// doi.org/10.1016/j.jfludis.2011.12.001

De Nil, L. F. \& Brutten, G. J. (1991). Speechassociated attitudes of stuttering and nonstuttering children. Journal of Speech and Hearing Research, 34, 60-66. https://doi. org/10.1044/jshr.3401.60

Erickson, S. \& Block, S. (2013). The social and communication impact of stuttering on adolescents and their families. Journal of Fluency Disorders, 38, 311-324. https://doi. org/10.1016/j.jfludis.2013.09.003

Ezrati-Vinacour, R., Platzky,R. \& Yairi, E. (2001). The young child's awareness of stuttering-like disfluency. Journal of Speech and Hearing Research, 44, 368-380. https:// doi.org/10.1044/1092-4388(2001/030)

Gerlach, H., Totty, E., Subramanian, A. \& Zebrowski, P. (2018). Stuttering and labor market outcomes in the United States. Journal of
Speech, Language and Hearing Research, 13, 61, 1649-1663. https://doi.org/10.1044/2018_ jslhr-s-17-0353

Iverach, L., Jones, M., O 'Brien, S., Block, S., Lincoln, M., Harrison, E., Hewat, S., Menzies, R., Packman, A. \& Onslow, M. (2009). Screening for personality disorders among adults seeking speech treatment for stuttering. Journal of Fluency Disorders, 34, 173-187. https://doi.org/10.1016/j.jlludis.2009.09.001 Iverach, L., Jones, M., O'Brien, S., Block, S., Lincoln, M., Harrison, E., Hewat, S., Menzies, R., Packman, A. \& Onslow, M. (2010). Mood and substance use disorders among adults seeking speech treatment for stuttering. Journal of Speech, Language and Hearing Research, 53, 1178-1190. https://doi.org/10.1044/10924388(2010/09-0166)

Iverach, L. \& Rapee, R. (2014). Social anxiety disorder and stuttering: Current status and future directions. Journal of Fluency Disorders, 40, 69-82. https://doi.org/10.1016/j. jfludis.2013.08.003

Jansson-Verkasalo, E., Lindblad, S., Vastamäki, E., Eggers, K. \& Vanryckeghem, M. (2021). KiddyCAT ja BigCAT -itsearviointilomakkeiden suomennosten normatiiviset ja psykometriset ominaisuudet. Pube ja kieli, 41, 189-206.

Klombas, M. \& Ross, E. (2004). Life experiences of people who stutter, and the perceived impact of stuttering on quality of life: personal accounts of South African individuals. Journal of Fluency Disorders, 29, 275-305. https://doi. org/10.1016/j.jlludis.2004.10.001

Koedoot, C., Versteegh, M. \& Yaruss, S. (2011). Psychometric evaluation of the Dutch translation of the Overall Assessment of the Speaker's Experience of Stuttering for adults (OASES-A-D). Journal of Fluency Disorders, 36, 222-230. https://doi.org/10.1016/j. jfludis.2011.03.002

Laitinen, O. (2016). OASES-A-arviointimenetelmän suomenkielinen käännös aikuisten änkytyksen arvioinnissa. Pro gradu -tutkielma. Turun yliopisto.

Langevin, M., Packman, A. \& Onslow, M. (2010). Parent Perceptions of the Impact of Stuttering on their Preschoolers and themselves. Journal of Fluency Disorders, 43, 407-423. https://doi. org/10.1016/j.jcomdis.2010.05.003 
Lankman, R., Yaruss, S. \& Franken, M-C. (2015). Validation and evaluation of the Dutch translation of the Overall Assessment of the Speaker's Experience of Stuttering for Schoolage children (OASES-SD). Journal of Fluency Disorders, 45, 27-37. https://doi 10.1016/j. jfludis.2015.05.003

Leith, W., Mahr, G., \& Miller, L. (1993). The assessment of speech-related attitudes and beliefs of people who stutter. ASHA Monographs Number 29. American Speech-LanguageHearing Association.

Lindström, E., Nilsson, E., Nilsson, J., Schödin, I., Strömberg, N., Österberg, S., Yaruss, J. S. \& Samson, I. (2020). Swedish outcomes of the Overall Assessment of the Speaker's Experience of Stuttering in an international perspective. Logopedics, Phoniatrics, Vocology, 45, 181-189. https://doi.org/10.1080/14015439.2019.169 5930

Manning, W. H. \& DiLollo, A. (2018). Clinical decision making in fluency disorders. Plural Publishing.

McAllister, J., Collier, J. \& Shepstone, L. (2012). The impact of adolescent stuttering on educational and employment outcomes: Evidence from a birth cohort study. Journal of Fluency Disorders, 37, 106-121. https://doi. org/10.1016/j.jfludis.2012.01.002

Menzies, R., O 'Brien, S., Onslow, M., Packman, A., St Clare, T. \& Block, S. (2008). An Experimental Clinical Trial of a CognitiveBehavior Therapy Package for Chronic Stuttering. Journal of Speech, Language and Hearing Research, 51, 1451-1464. https:// doi.org/10.1044/1092-4388 (2008/070070)

Murphy, W., Yaruss, J. S. \& Quesal, R. (2007a). Enhancing treatment for school-age children who stutter I. Reducing negative reactions through desensitization and cognitive restructuring. Journal of Fluency Disorders, 32, 121-138. https://doi.org/10.1016/j. jlludis.2007.02.001

Murphy, W., Yaruss, J. S. \& Quesal, R.W. (2007b). Enhancing treatment for school-age children who stutter II. Reducing bullying through role-playing and self-disclosure. Journal of Fluency Disorders, 32, 139-162. https://doi. org/10.1016/j.jfludis.2007.02.001
Mäntylä, L. (2017). 13-17-vuotiaille änkyttäville henkilöille suunnatun OASEST-kyselylomakkeen suomenkielisen version reliabiliteetti. Pro gradu -tutkielma. Turun yliopisto.

O'Brian, S., Heard, R., Onslow, M., Packman, A., Lowe, R. \& Menzies, R. (2020). Clinical Trials of Adult Stuttering Treatment: Comparison of Percentage Syllables Stuttered With SelfReported Stuttering Severity as Primary Outcomes. Journal of Speech, Language and HearingResearch, 63, 1387-1394.https://doi. org/10.1044/2020_JSLHR-19-00142

O'Brian, S., Jones, M., Packman, A., Menzies, R. \& Onslow, M. (2011). Stuttering severity and educational attainment. Journal of Fluency Disorders, 36, 86-92. https://doi. org/10.1016/j.jfludis.2011.02.006

Riley, G. (1994). Stuttering Severity Instrument, 4. painos. Pro ED.

Sakai, N., Chu, S. Y., Mori, K. \& Yaruss, J. S. (2017). The Japanese version of the Overall Assessment of the Speaker's Experience of Stuttering for adults (OASES-A-J): Translation and psychometric evaluation. Journal of Fluency Disorders, 51, 50-59. https://doi. org/10.1016/j.jfludis.2016.11.002

Singer,C., Hessling, A., Kelly, E., Singer, L. \& Jones, R. (2020). Clinical characteristics associated with stuttering persistence: A meta-analysis. Journal of Speech, Language and Hearing Research, 63, 2995-3018. https://doi. org/10.1044/2020

St Clare, T., Menzies, R., Onslow, M., Packman, A., Thompson, R. \& Block. S. (2009). Unhelpful thoughts and beliefs linked to social anxiety in stuttering: Development of a measure. International Journal of Language \& Communication Disorders, 44. 338 -351.

St. Louis, K. O., Sønsterud, H., Junuzovic-Žunic, L., Tomaiuoli, D., Del Gadoe, F., Caparelli, E., Theiling, M., Flobakk, C., Nesbakken Helmen, L., Heitmann, R. R., Kvenseth, H., Nilsson, S., Wetterling, T., Lundström, C., Daly, C., Leahy, M., Tyrrell, L., Ward, D. \& Węsierska, M. (2016). Public attitudes toward stuttering in Europe: Within-country and between-country comparisons. Journal of Communication Disorders, 62, 115-130. https://doi. org/10.1016/j.jcomdis.2016.05.010 
Terveyden ja hyvinvoinnin laitos (2013). ICFmalli suomeksi. Haettu 6.4.2020 osoitteesta https://thl.fi/fi/web/toimintakyky/icfluokitus.

Vahanne, U. (2017). OASES-S-arviointilomakkeen suomenkielinen käännös lasten änkytyksen arvioinnissa. Pro gradu -tutkielma. Turun yliopisto.

Van Riper, C. (1982) The nature of stuttering. Prentice Hall.

Vanryckeghem, M. \& Brutten, G. J. (1996). The relationship between communication attitude and fluency failure of stuttering and nonstuttering children. Journal of Fluency Disorders, 21, 109-118. https://doi. org/10.1016/0094-730X(96)00015-0

Vanryckeghem, M. \& Brutten, G. J. (2007). KiddyCAT: Communication Attitude Test for Preschool and Kindergarten Children Who Stutter. Plural Publishing Inc.

Vanryckeghem, M. \& Brutten, G. (2016). Behavior Assessment Battery for adults who stutter. Plural Publishing Inc.

Vanryckeghem, M., Hylebos, C., Brutten G. J. \& Peleman, M. (2001). The relationship between communication attitude and emotion of children who stutter. Journal of Fluency Disorders, 26, 1-15. https://doi.org/10.1016/ S0094-730X(00)00090-5

WHO (2001). ICF-mallin käsikirja. Haettu 6.4.2020 osoitteesta https://www.who.int/ classifications/drafticfpracticalmanual2. pdf ?ua $=1$

WHO (2016). ICD-10, F98.5 Stuttering. Haettu 6.4.2020 osoitteesta http://apps.who.int/ classifications/icd10/browse/2016/en\#/F98.5

WHO (2017). Process of translation and adaptation of instruments. Haettu 18.5.2021 osoitteesta https://www.who.int/substance_ abuse/research_tools/translation/en/

Wright, L. \& Ayre, A. (2000). WASSP: The Wright and Ayre stuttering self-rating profile. Speechmark Publishing Limited.

Yaruss, J. S. (1998). Describing the consequences of disorders: Stuttering and the International Classification of Impairments, Disabilities, and Handicaps. Journal of Speech, Language and Hearing Research, 49, 249-257. https://doi. org/10.1044/jslhr.4102.249
Yaruss, J. S. (2007). Application of the ICF in fluency disorders. Seminars in Speech and Language, 28, 312-322. https://doi. org/10.1055/s-2007-986528

Yaruss, J. S. \& Quesal, R. W. (2004). Stuttering and the International Classification of Functioning, Disability, and Health (ICF): An update. Journal of Communication Disorders, 37, 35-52. https://doi.org/10.1016/s00219924(03)00052-2

Yaruss, J. S. \& Quesal, R. W. (2006). Overall Assessment of the Speaker's Experiences of Stuttering (OASES): Documenting multiple outcomes in stuttering treatment. Journal of Fluency Disorders, 31, 90-115. https://doi. org/10.1016/j.jfludis.2006.02.002

Yaruss, J. S. \& Quesal, R. W. (2016). Overall Assessment of the Speaker's Experiences of Stuttering (OASES). Stuttering Therapy Resources. 


\section{THE VALIDITY AND RELIABILITY OF THE FINNISH VERSIONS OF THE OASES PATIENT-REPORTED OUTCOME MEASURES}

Eira Jansson-Verkasalo, Dept. of Psychology and Speech-Language Pathology, University of Turku Auli Laiho, Stuttering Resource Center Tempo

J.S. Yaruss, Communicative Sciences and Disorders, Michigan State University, East Lansing, MI

The Overall Assessment of the Speaker's Experience of Stuttering (OASES ${ }^{\text {тм} ; ~ Y a r u s s ~ \& ~ Q u e s a l, ~}$ 2016) is a patient-reported outcome measure that was designed to provide a comprehensive assessment of "the experience of the stuttering disorder from the perspective of individuals who stutter" (Yaruss \& Quesal, 2006, p. 90). The aim of the present study was to evaluate the validity and reliability of the authorized Finnish adaptations of the OASES-S (for school-age children, ages 7-12), OASES-T (for teens, ages 13-17), and the OASES-A (for adults ages 18 and above). In this research, 60 school-aged children completed the OASES-S response forms with 60 statements, 31 teenagers completed the OASES-T response forms with 80 statements, and 31 adults completed the OASES-A response forms with 100 statements. The analyses of external (age), construct (correlation between different sections) and content (descriptive comparison between the Finnish and English OASES scores) validity indicated that the Finnish OASES questionnaires are valid measures. The age of the participant did not have an effect on the results indicating good external validity. The mean scores were descriptively close to those of the English version. Internal consistency and re-test reliabilities were high for both measures. The alpha scores of the OASES-S, OASES-T and OASES-A were high $(\alpha 0,82-0,95)$ indicating good internal consistency. Similarly test-retest reliability demonstrated high consistency of responses $(r=0,65-0,97)$ from one administration to the next, except for the OASES-A Part I (General information). To conclude, the Finnish OASES-S, OASES-T and OASES-A validly and reliably measure the impact of stuttering on the Finnish children, teenagers, and adults. The titles of the impact ratings may be changed to equal to the Finnish clinical terminology. Moreover, further research is needed on the cultural differences of the experience of stuttering and the assessment of the experience to get the measures more sensitive for different cultures.

Keywords: assessment methods, OASES, quality of life, stuttering 
